\title{
Ethanol Vapor Vacuum Infiltration of Tomatoes: Morphological Analysis and Effect on Ripening and Eating Quality
}

\author{
B. Ratanachinakorn \\ Horticulture Research Institute, Department of Agriculture, Chatuchak, Bangkok 10900, Thailand
}

A. Klieber ${ }^{1}$

Department of Horticulture, Viticulture, and Oenology, The University of Adelaide, Waite Campus PMB

1, Glen Osmond, SA 5064, Australia

D.H. Simons

Department of Plant Production, University of Queensland, Gatton College, Qld 4343, Australia

ADDITIONAL INDEX wORDS. Lycopersicon esculentum, flavor, aroma, acetaldehyde

\begin{abstract}
Tomatoes (Lycopersicon esculentum Mill. 'Bermuda') were vacuum infiltrated at the breaker stage with 25 to $55 \mathrm{~mL} \cdot \mathrm{L}^{-1}$ ethanol $(\mathrm{EtOH})$ vapor at a $10 \mathrm{kPa}$ pressure for 5 minutes and then held for a further period before ripening in air at $22{ }^{\circ} \mathrm{C}$. Fruit could tolerate these $\mathrm{EtOH}$ vapor concentrations for no longer than 0 to 12 hours after vacuum infiltration, depending on concentration; otherwise skin pitting, uneven ripening and off-flavors resulted. Noninjurious conditions delayed ripening, as judged by color change, by an additional 1 to 5 days compared with 4 days for the control; aroma or flavor were not altered as determined by a trained taste panel, except in extreme conditions where in some cases off-flavors increased. Soluble solids and titratable acidity did not vary, but pH increased by 0.1 units in some treatments. In control fruit EtOH was found only in the gel tissue, and acetaldehyde (AA) was higher in the gel tissue compared with the pericarp and columella, indicating different metabolic behavior of the various tomato tissues. During vacuum exposure, EtOH moved through the stem scar and to a much lesser extent through the epidermis; during subsequent exposure to EtOH more EtOH moved through the epidermis than before, but still less than through the stem scar. AA increased following EtOH uptake, but all increases in EtOH and AA disappeared before fruit ripened.
\end{abstract}

Fresh tomatoes are claimed to lack both taste and aroma (McGlasson et al., 1982). Postharvest treatments using short term controlled atmospheres (CA) or exposure of fruit to volatile compounds such as AA or EtOH can improve the flavor of some fruit by inducing production of complex aroma compounds, for example improving the flavor of strawberries (Fragaria $\times a n a n-$ assa Duch.) (Pesis and Avissar, 1990), feijoas (Feijoa sellowiana Berg.) (Pesis et al., 1991), and citrus (Citrus sp. L.) (Pesis and Avissar, 1989; Shaw et al., 1991). However, using short term CA did not improve tomato aroma or flavor (Ratanachinakorn et al., 1997). While these CA treatments induced an increase in AA and EtOH levels, these compounds disappeared again by the time fruit were ripe and had not been sufficiently remetabolized to alter taste.

Vacuum infiltration of a vapor is a rapid method to increase the volatile content of fruit tissues. This approach has been used to infiltrate AA into strawberries to control insects (Aharoni et al., 1980) and butanal into 'Valencia' oranges [Citrus sinensis (L.) Osbeck] (Lizotte and Shaw, 1992) to increase the volatile content of processed product. The vacuum used to infiltrate the volatiles into the fruit varied and no information is available for this technique on tomatoes. The number of volatiles and complexity of the volatiles synthesized by exogenously supplied precursors is time dependent (Berger et al., 1992; Yamashita et al., 1975, 1976) and therefore an exposure period may be essential for improving tomato flavor using $\mathrm{EtOH}$ vacuum infiltration. Continuous exposure to $\mathrm{EtOH}$ delayed ripening of tomatoes (Hong et al., 1995; Kelly and Saltveit, 1988;

Received for publication 1 Oct. 1997. Accepted for publication 4 Jan. 1999. The cost of publishing this paper was defrayed in part by the payment of page charges. Under postal regulations, this paper therefore must be hereby marked advertisement solely to indicate this fact.

${ }^{1}$ To whom reprint requests should be addressed.
Saltveit and Sharaf, 1992) due to enzymic conversion by alcohol dehydrogenase $(\mathrm{ADH})$ to the ripening inhibitor $\mathrm{AA}$ (Beaulieu and Saltveit, 1997; Beaulieu et al., 1997). However, no controlled sensory analysis of flavor changes was carried out. The objective of this study was to determine the limits of exposure to $\mathrm{EtOH}$ vapor through vacuum infiltration and static exposure in tomatoes, its distribution in and dissipation from the fruit and whether this approach was effective in improving the sensory quality of the tomatoes in contrast to indirect changes in $\mathrm{EtOH}$ and AA caused by CA (Ratanachinakorn et al., 1997).

\section{Materials and Methods}

'Bermuda' tomatoes at the breaker color stage were obtained from a commercial grower in the Gatton area, South East Queensland, Australia. Hand picked, sound medium-sized fruit, 110 to 130 $\mathrm{g}$ (fresh mass basis), were preselected in the field. To compare the amount of air evacuated from tomatoes under different vacuums, individual fruit were submerged in water in a $10-\mathrm{L}$ vacuum container and covered with a funnel connected to a graduated cylinder filled with water. The container was then evacuated to 70,40 , or $10 \mathrm{kPa}$ pressure with a 5-min exposure. The air evacuated from the fruit replaced the water in the cylinder and could thus be measured. Fifteen fruit were tested for each level of vacuum.

VISUAL QUALITY. The effect of these vacuums on visual injury and firmness of the fruit held in air was evaluated in three replications after placing 10 breaker fruit each in a $10-\mathrm{L}$ vacuum container in air and evacuating it to 70,40 , or $10 \mathrm{kPa}$ pressure with a 5-min exposure. After repressurizing, the fruit were stored at $22{ }^{\circ} \mathrm{C}$ until ripe as indicated by a red ripe color. The fruit were then observed for any visual defects on the skin and firmness of tomatoes was measured as by Klieber et al. (1996). 
To determine the effect of EtOH vapor on the quality of breaker harvested tomatoes, 2 replicates of 8 fruit each were placed in a 10$\mathrm{L}$ vacuum container with $1,5,10$, or $20 \mathrm{~mL}$ of absolute $\mathrm{EtOH}$. The fruit were then evacuated to $10 \mathrm{kPa}$ pressure with a 5-min exposure and another 5 min for repressurising. The EtOH vapor concentrations in air in the 10 -L container after repressurising, as determined by flame ionization gas chromatography (Klieber et al., 1996), were $25,35,45$, and $55 \mathrm{~mL} \cdot \mathrm{L}^{-1}$ for $1,5,10$, and $20 \mathrm{~mL}$ treatments, respectively. The fruit were also further held under the $\mathrm{EtOH}$ atmosphere in static conditions for $0,1,3,6$, or $12 \mathrm{~h}$ before transfer to normal air for ripening. Visual fruit skin injury was recorded, using both the scale described above and color change during ripening.

Sensory evaluation. 'Bermuda' tomatoes at the breaker stage were prepared as above. Ten fruit were vacuum infiltrated with EtOH vapor generated from 1, 5, 10, and $20 \mathrm{~mL}$ of absolute EtOH. The vacuum infiltration procedure was the same as in the previous section. Fruit were held in the vacuum for $5 \mathrm{~min}$ and another $5 \mathrm{~min}$ after repressurising, which was considered as $0 \mathrm{~h}$ exposure time. Vacuum infiltrated fruit were further held in their respective $\mathrm{EtOH}$ atmospheres for an additional 1 or $3 \mathrm{~h}$ and then were stored in cartons at $22^{\circ} \mathrm{C}$ to ripen for tasting. Each treatment was replicated three times, using fruit from three harvests, with ten fruit samples. For tasting, four to five fruit of each treatment were prepared by dicing and mixing fruit and tasted as detailed by Ratanachinakorn et al. (1997). Each replicate was tasted once by six trained tasters. Quantitative descriptive analysis was carried out using a $15 \mathrm{~cm}$ unstructured scale anchored at both ends; the anchors for tomato aroma, green aroma, and off-flavor were $0=$ none and $15=$ extreme; for blandness were $0=$ most bland and $15=$ not bland; and for sweet-sour balance were $0=$ sweet and $15=$ sour. The number of samples tasted per session varied according to the ripeness of the fruit.

Fruit prepared for sensory evaluation were also sampled for analysis of soluble solids, titratable acidity and $\mathrm{pH}$ as detailed by Ratanachinakorn et al. (1997).

Morphological analysis. To compare the distribution and dissipation of EtOH in tomato tissues, $10 \mathrm{~mL}$ absolute EtOH was used in the 10-L container. Fruit were vacuum infiltrated as above and further held in $\mathrm{EtOH}$ vapor for 0 or $3 \mathrm{~h}$ after repressurising. A fruit from each replicate was sampled for volatile analysis immediately after removal from the $\mathrm{EtOH}$ atmosphere and on days 2, 4, or 6 during storage at $22{ }^{\circ} \mathrm{C}$ for ripening in air. EtOH and $\mathrm{AA}$ were determined in the equatorial outer pericarp, the gel and columella tissue from the stem end, equator and blossom end areas of the fruit. Tomato gel excluding seed, outer pericarp and columella tissues was excised from the fruit at $4{ }^{\circ} \mathrm{C}$ and blotted dry with a paper towel before being cut into 0.4 to $0.5 \mathrm{~cm}$ sided cubes. One gram samples were then frozen in liquid $\mathrm{N}_{2}$ and sealed with rubber stoppers in precooled $12-\mathrm{mL}$ test tubes. The headspace volume was $11 \mathrm{~mL}$. All samples were stored at -18 to $-20^{\circ} \mathrm{C}$ and were analyzed on the following day.

To analyze for $\mathrm{AA}$ and $\mathrm{EtOH}$, frozen samples were thawed at 0 to $2{ }^{\circ} \mathrm{C}$ in sealed $12-\mathrm{mL}$ test tubes for $60 \mathrm{~min}$ before heating at $30{ }^{\circ} \mathrm{C}$ for $60 \mathrm{~min}$. One milliliter headspace samples were drawn from the test tubes and analyzed as described by Klieber et al. (1996) using flame ionization gas chromatography. Each treatment was replicated three times with eight fruit each and the experiment was repeated twice. All experiments were conducted at $22{ }^{\circ} \mathrm{C}$.

All data were subjected to analysis of variance, and means were compared by least significant difference (LSD) at a 5\% level of significance using a SAS version 6.08 program (SAS Institute, Cary, N.C.). Unless noted otherwise, only results significant at $P$ $=0.05$ are discussed.

\section{Results}

VISUAL QUALITY. The amount of air evacuated was highest at 10 $\mathrm{kPa}$ pressure (53 mL/fruit) and this level of reduced pressure did not cause visual injury to the fruit during ripening. The firmness of the fruit evacuated to $10 \mathrm{kPa}$ pressure was not different from the no-vacuum control, and was $1.7 \mathrm{~N}$ when fruit were red ripe. Thus, a $10 \mathrm{kPa}$ pressure was used in later experiments.

Skin injury, expressed as pitting and uneven color development during ripening, was the limiting factor for EtOH vapor vacuum infiltration. The severity and incidence of the injury increased with increased exposure time and EtOH level; breaker tomatoes were injured by exposure to $\mathrm{EtOH}$ vapor from 5 and 10 to $20 \mathrm{~mL} \mathrm{EtOH}$ in a $10-\mathrm{L}$ container for more than 6 or $3 \mathrm{~h}$, respectively (Table 1 ). Fruit failed to reach a red-ripe color altogether when exposed to an EtOH vapor produced from $20 \mathrm{~mL}$ for $12 \mathrm{~h}$.

When noninjurious concentrations and holding times were employed, EtOH vapor delayed ripening (Table 1) without inducing visual injury when ripe. The higher the concentration of EtOH in the atmosphere, provided that the exposure time was $1 \mathrm{~h}$ or more, and the longer the exposure time the longer was the ripening delay. The longest ripening delay of $5.6 \mathrm{~d}$ in addition to a control of $4.2 \mathrm{~d}$ was achieved by $5 \mathrm{~mL}$ EtOH in a 10-L container with $6 \mathrm{~h}$ exposure.

Sensory Evaluation. The tomatoes used in this experiment had a medium intensity of tomato aroma, with a score of $53 \%$, a mild green aroma, with a score of $7 \%$, a very low off-flavor, with a score of $6 \%$, a balanced sweet-sour taste, with a score of $51 \%$, and an intensity in the middle between bland and intense, with a score of $47 \%$ on the intensity scale used (Table 2). Vacuum infiltration of fruit with EtOH vapor with or without prolonged exposure did not affect these attributes when the breaker fruit had ripened. In some fruit an increased intensity of off-flavor was found associated with elevated $\mathrm{EtOH}$ levels and prolonged exposures, but this was only associated with one replicate resulting in large standard errors (Table 2).

The soluble solids and titratable acidity of the tomatoes ranged between 0.38 and $0.44 \mathrm{~g} \cdot \mathrm{L}^{-1}$ of juice and $\mathrm{H} \mathrm{H}^{+}$concentration of 89 to $130 \mathrm{mmol} \cdot \mathrm{L}^{-1}$ of juice, respectively. EtOH vacuum infiltration had no consistent effect on these measurements. The $\mathrm{pH}$ of the control fruit was 4.27, and vacuum infiltration with $10 \mathrm{~mL} \mathrm{EtOH}$ plus exposure or $20 \mathrm{~mL}$ with or without exposure increased the $\mathrm{pH}$ of the fruit to 4.35 to 4.39 .

MorPhOlOGiCAL LOCATION. In control fruit, EtOH was found only in the gel tissues and it remained at a constant level throughout storage (Fig. 1). AA was found at the highest level in the gel followed by the columella tissues, and to a much lesser extent in the outer pericarp (Fig. 1). AA concentrations declined with storage, except in the outer pericarp, which had a low AA content. Fruit were red ripe in $<6 \mathrm{~d}$.

For $\mathrm{EtOH}$ vacuum infiltrated fruit without exposure, EtOH increased to the highest levels in the stem end columella tissues, and to much lesser levels in the outer pericarp, followed by the equatorial columella tissue (Fig. 2). There was no detectable EtOH in the blossom end columella tissue and the gel tissues contained similar levels to the control. On day 2 all applied EtOH had dissipated with no EtOH detected in the pericarp or columella. 
Table 1. Ripening time of breaker 'Bermuda' tomatoes vacuum infiltrated with different ethanol vapor concentrations and exposure times. Values are means of two replications of eight fruit each \pm standard error of means.

\begin{tabular}{|c|c|c|c|c|c|}
\hline \multirow{2}{*}{$\begin{array}{l}\text { Ethanol } \\
(\mathrm{mL} / 10 \mathrm{~L})\end{array}$} & \multicolumn{5}{|c|}{ Ripening time (d) after EtOH exposure (h) } \\
\hline & 0 & 1 & 3 & 6 & 12 \\
\hline Control & $4.2 \pm 0.1$ & & & & \\
\hline 1 & $4.5 \pm 0.7$ & $4.5 \pm 0.7$ & $6.2 \pm 0.1$ & $6.5 \pm 0.3$ & $7.3 \pm 0.3$ \\
\hline 5 & $5.0 \pm 0.0$ & $4.9 \pm 0.1$ & $8.2 \pm 1.1$ & $9.8 \pm 0.3$ & $---^{z}$ \\
\hline 10 & $4.5 \pm 0.7$ & $6.7 \pm 0.3$ & $8.2 \pm 1.1$ & --- & --- \\
\hline 20 & $4.8 \pm 0.3$ & $7.3 \pm 0.3$ & $9.2 \pm 0.3$ & --- & --- \\
\hline 30 & $5.0 \pm 0.0$ & $7.4 \pm 0.8$ & --- & --- & --- \\
\hline 40 & $5.6 \pm 0.8$ & --- & --- & --- & --- \\
\hline $\operatorname{SE}(\mathrm{n}=70, \mathrm{df}=35)$ & \multirow{2}{*}{\multicolumn{5}{|c|}{$\mathrm{C}^{* * * *}, \mathrm{E}^{2 * *}, \mathrm{C} \times \mathrm{E}^{* * * *}$}} \\
\hline Significant effect & & & & & \\
\hline
\end{tabular}

${ }^{* * *}$ Significant at $P<0.005$; ethanol concentration $=\mathrm{C}$ and exposure time $=\mathrm{E}$.

AA increased most markedly in the stem end columella and the outer pericarp tissue, compared with the controls (Fig. 2). The other tissues contained similar levels to the control. After $2 \mathrm{~d}$ all AA levels were similar to the controls and fruit were red ripe in $<6$ d.

Fruit that were vacuum infiltrated with EtOH followed by an exposure time of $3 \mathrm{~h}$ contained more $\mathrm{EtOH}$ and $\mathrm{AA}$ in all parts of the fruit than fruit without exposure (Fig. 3). The highest concentrations of $\mathrm{EtOH}$ and $\mathrm{AA}$ were found in the stem end tissue of the columella. EtOH and $\mathrm{AA}$ in the stem end columella greatly decreased on day 2 of storage, while both increased markedly in the columella tissues around the equator and blossom end on day 2 . Both volatiles decreased again on day 4 of storage in all columella tissues returning to control levels in $6 \mathrm{~d}$. EtOH and $\mathrm{AA}$ increased in the gel on day 2 of storage before returning to day 0 levels on day 4. However, levels remained higher than in control fruit. In the pericarp tissue $\mathrm{EtOH}$ and $\mathrm{AA}$ were much higher than the control throughout day 0 to 6 . Fruit did not fully ripen in this period.

\section{Discussion}

Visual QUaLITY AND RIPENING Delay. EtOH vapor caused visible skin injury to tomatoes within $1 \mathrm{~d}$ of application for extreme combinations of EtOH level and exposure, and the severity of injury was higher with a longer exposure time and higher EtOH concentration. Similarly, Savarese and Mencarelli (1989) found that exposure to EtOH vapor causes skin injury in several tomato cultivars. The injury may be a result of high EtOH absorption and accumulation in the skin and pericarp; however, it is more likely that AA produced from EtOH by alcohol dehydrogenase caused the injury. AA vapor causes skin injury in some cultivars of tomatoes (Pesis and Marinansky, 1993) and is toxic to carrot cells, but EtOH is not (Perata and Alpi, 1991).

Ripening was delayed by EtOH vapor infiltration in this study as has been reported for various ripening stages of tomatoes exposed to EtOH vapor under static conditions for 2 to $24 \mathrm{~h}$ (Hong et al., 1995; Kelly and Saltveit, 1988; Saltveit and Sharaf, 1992; Savarese and Mencarelli, 1989). Vacuum infiltration of an EtOH solution placed on the stem scar of the fruit also delays the ripening of 'Recento' tomatoes (Hong et al., 1995). The delay in ripening was possibly a result of $\mathrm{EtOH}$ inhibiting the conversion of ACC to ethylene (Saltveit, 1989), and/or delaying chlorophyll degradation (Corcuff et al., 1996; Hong et al., 1995) and lycopene synthesis (Hong et al., 1995; Saltveit, 1989; Saltveit and Mencarelli, 1988). AA, produced by alcohol dehydrogenase from $\mathrm{EtOH}$, causes this delay in ripening of the fruit. AA delays

Table 2. Sensory quality evaluated at red-ripe stage of breaker 'Bermuda' tomatoes vacuum infiltrated with different ethanol vapor concentrations and exposure times. Values are means of three replications of six tasters \pm standard error of means.

\begin{tabular}{|c|c|c|c|c|c|c|}
\hline \multirow{2}{*}{$\begin{array}{l}\text { Sensory } \\
\text { attribute }^{z}\end{array}$} & \multirow{2}{*}{$\begin{array}{c}\text { Exposure } \\
\text { time (h) }\end{array}$} & \multicolumn{5}{|c|}{ Ethanol (mL/10 L) } \\
\hline & & 0 & 1 & 5 & 10 & 20 \\
\hline \multirow[t]{3}{*}{ Tomato aroma } & 0 & $7.3 \pm 0.8$ & $9.0 \pm 1.4$ & $8.7 \pm 0.8$ & $7.4 \pm 1.5$ & $8.0 \pm 0.2$ \\
\hline & 1 & $9.0 \pm 1.7$ & $8.8 \pm 1.2$ & $7.9 \pm 0.2$ & $7.5 \pm 1.5$ & $8.4 \pm 0.3$ \\
\hline & 3 & $8.7 \pm 0.9$ & $8.4 \pm 0.5$ & $9.2 \pm 0.6$ & $8.6 \pm 0.8$ & $6.9 \pm 2.0$ \\
\hline \multirow[t]{3}{*}{ Green aroma } & 0 & $0.9 \pm 0.5$ & $1.6 \pm 1.5$ & $0.7 \pm 0.3$ & $1.0 \pm 0.2$ & $1.0 \pm 0.3$ \\
\hline & 1 & $1.5 \pm 1.2$ & $1.0 \pm 0.7$ & $1.4 \pm 1.2$ & $0.7 \pm 0.2$ & $1.7 \pm 1.9$ \\
\hline & 3 & $1.1 \pm 0.4$ & $0.9 \pm 0.8$ & $1.1 \pm 0.8$ & $0.7 \pm 0.2$ & $0.8 \pm 0.3$ \\
\hline \multirow[t]{3}{*}{ Off-flavor } & 0 & $0.5 \pm 0.2$ & $0.6 \pm 0.5$ & $0.6 \pm 0.2$ & $1.2 \pm 0.3$ & $1.3 \pm 0.8$ \\
\hline & 1 & $0.5 \pm 0.2$ & $0.4 \pm 0.4$ & $0.6 \pm 0.3$ & $1.5 \pm 0.5$ & $1.6 \pm 1.9$ \\
\hline & 3 & $0.3 \pm 0.2$ & $0.9 \pm 0.3$ & $1.2 \pm 1.0$ & $2.0 \pm 2.3$ & $0.8 \pm 0.5$ \\
\hline \multirow[t]{3}{*}{ Sweet-sour balance } & 0 & $7.6 \pm 0.4$ & $8.6 \pm 0.9$ & $7.2 \pm 0.2$ & $7.6 \pm 0.5$ & $7.4 \pm 0.8$ \\
\hline & 1 & $7.7 \pm 0.2$ & $8.1 \pm 1.2$ & $7.8 \pm 0.9$ & $7.3 \pm 0.8$ & $7.2 \pm 1.2$ \\
\hline & 3 & $7.6 \pm 0.5$ & $6.8 \pm 1.0$ & $6.7 \pm 0.1$ & $7.9 \pm 1.5$ & $7.6 \pm 0.8$ \\
\hline \multirow[t]{3}{*}{ Blandness } & 0 & $6.9 \pm 0.9$ & $8.3 \pm 0.4$ & $6.1 \pm 1.7$ & $6.8 \pm 1.3$ & $6.6 \pm 1.7$ \\
\hline & 1 & $7.4 \pm 1.8$ & $7.2 \pm 0.4$ & $7.3 \pm 1.1$ & $5.9 \pm 2.2$ & $6.0 \pm 0.8$ \\
\hline & 3 & $7.5 \pm 1.3$ & $5.4 \pm 0.8$ & $7.0 \pm 2.3$ & $7.2 \pm 0.4$ & $7.7 \pm 0.6$ \\
\hline
\end{tabular}

${ }^{\mathrm{z}} \mathrm{A}$ score of 0 was the lowest and 15 the highest possible score, 7.5 indicated an even balance (sweet-sour) and 0 was the most bland.

${ }^{\mathrm{NS}}$ Nonsignificant at $P<0.05$; ethanol concentration $=\mathrm{C}$ and exposure time $=\mathrm{E}$. All significant effects were $\mathrm{C}^{\mathrm{Ns}}, \mathrm{E}^{\mathrm{NS}}$, and $\mathrm{C} \times \mathrm{E}^{\mathrm{Ns}}$. 

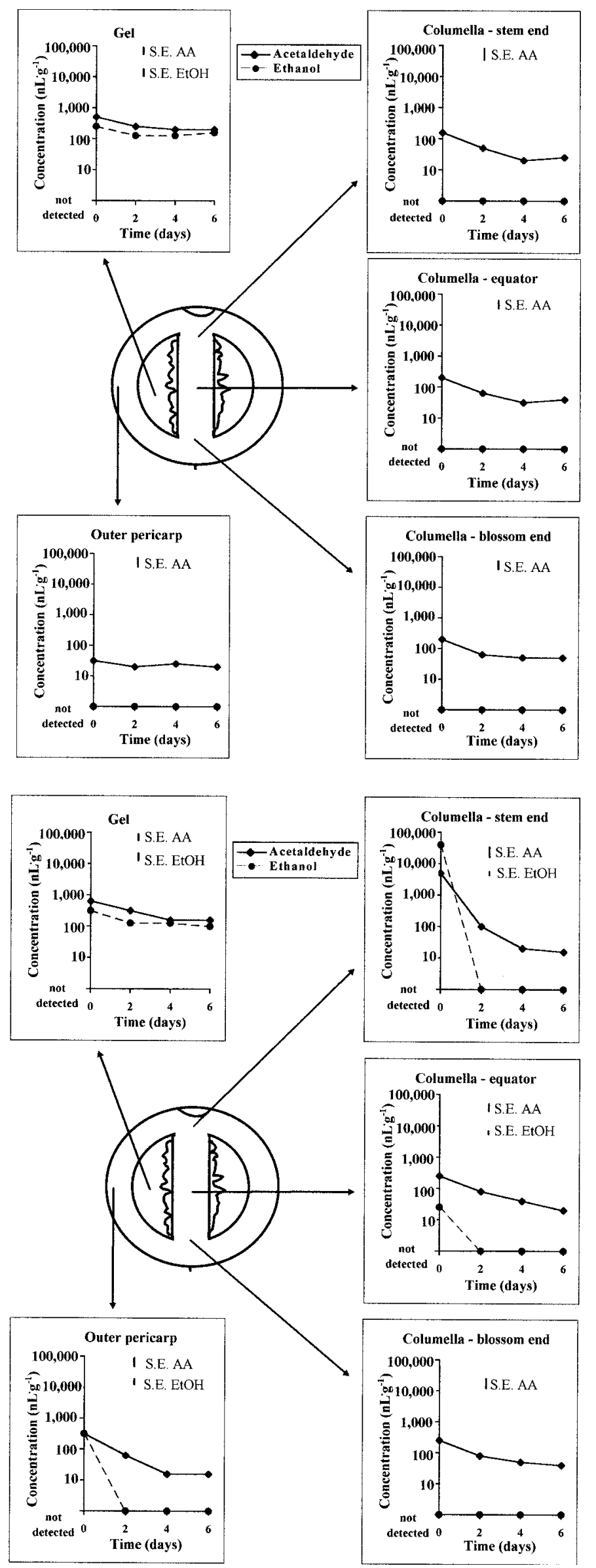

Fig. 1. Ethanol and acetaldehyde content of the outer pericarp, gel, and columella tissues of breaker harvested 'Bermuda' tomatoes after vacuum infiltration in air. Values are means of two replications of three fruit each analyzed in triplicate. The overall standard error of means is shown.

the ripening of some cultivars of tomatoes (Pesis and Marinansky, 1993; Pesis et al., 1994), and Beaulieu et al. (1997) and Beaulieu and Saltveit (1997) showed that the concentration of AA in the tissue is the important factor in delaying ripening rather than EtOH. Burdon et al. (1996) demonstrated in mango fruit discs that $\mathrm{AA}$ is more effective at inhibiting ethylene biosynthesis than $\mathrm{EtOH}$, as it has a higher inhibiting effect on ACC oxidase activity. Ripening of the fruit resumes as EtOH and AA dissipates from the fruit tissues, as AA falls below critical levels (Beaulieu et al., 1997, Beaulieu and Saltveit, 1997).

Excessive EtOH infiltration associated with a higher $\mathrm{EtOH}$ content in the vessel and a longer exposure time caused uneven ripening, expressed as a patchy skin color, or failure of the fruit to ripen, expressed by no color or texture changes. EtOH and AA vapor have been reported to cause uneven ripening in tomatoes (Kelly and Saltveit, 1988; Pesis and Marinansky, 1993). This may be caused by localized accumulation of EtOH and associated AA, which then do not dissipate in time for ripening and color development to proceed. In the morphological study discussed below we also found that EtOH and AA did not easily dissipate from the outer pericarp once it had accumulated.

Sensory Evaluation. In this study vacuum infiltration of EtOH did not improve tomato aroma or flavor, which was similar to short term CA exposure (Ratanachinakorn et al., 1997). This was despite the fact that the 3-h holding period with the same amount of ethanol infiltrated in our morphological study maintained sustained increases in EtOH and AA. This would have allowed their remetabolization into other aroma volatiles, but fruit did not express this once they were ripe. Increasing the $\mathrm{EtOH}$ vapor concentration and the exposure time did not increase offflavor overall; however, off-flavor intensity increased in one replication, which indicates the potential for off-flavor problems under the more extreme conditions. Grierson and Kader (1986) suggested that 2-methylbutanal, synthesized from isoleucine (Salunkhe and Do, 1977), contributes to off-flavor of tomatoes, but both AA and EtOH persisted at higher levels in the outer pericarp and gel tissues compared with controls suggesting that these compounds or their metabolites gave rise to the off-flavors in our study.

Buttery et al. (1995) reported that $\mathrm{pH}$ affects the intensity of aroma components. However, in this study, tomato and green aroma did not vary, but $\mathrm{pH}$ changes were small. Previous reports on the relationships of chemical components and taste in untreated tomatoes showed that $\mathrm{pH}$ had no consistent effect on the taste of tomatoes (Jones and Scott, 1984; Kader et al., 1977; Watada and Aulenbach, 1979).

Treatment with $1,000 \mu \mathrm{L} \cdot \mathrm{L}^{-1}$ AA for $24 \mathrm{~h}$ increases reducing sugars in tomatoes (Paz et al., 1981). AA induces gluconeogenesis, a sugar synthesis pathway (Halinska and Frenkel, 1991). However, in this study the sweetness, sourness and soluble solids were not affected by vacuum infiltration of EtOH vapor with or without an exposure time. It is possible that the AA level, arising by conversion of EtOH, was not sufficiently high to induce

Fig. 2. Ethanol and acetaldehyde content of the outer pericarp, gel, and columella tissues of breaker harvested 'Bermuda' tomatoes after vacuum infiltration with ethanol vapor from $10 \mathrm{~mL}$ absolute ethanol placed in a 10-L vessel without an exposure period after infiltration. Values are means of two replications of three fruit each analyzed in triplicate. The overall standard error of means is shown. 


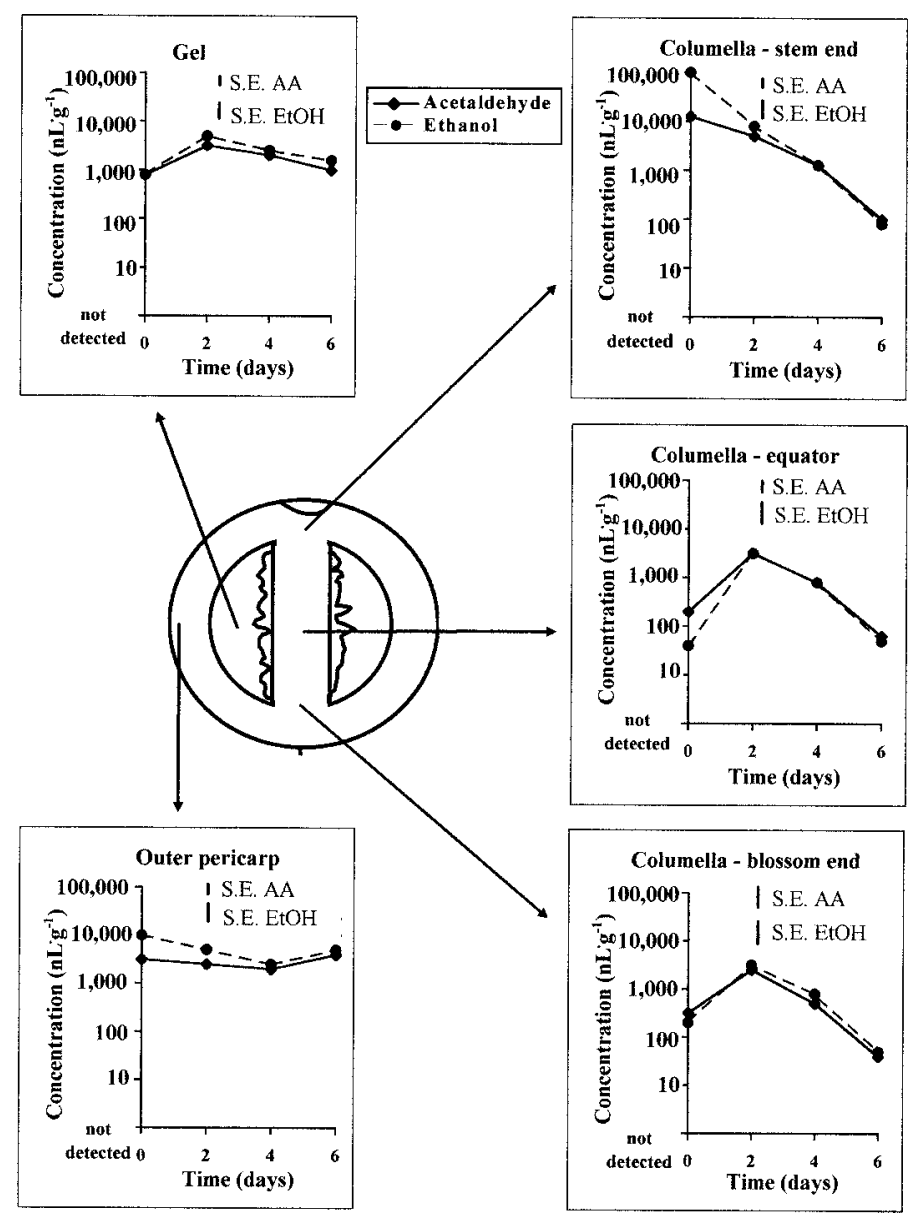

Fig. 3. Ethanol and acetaldehyde content of the outer pericarp, gel, and columella tissues of breaker harvested 'Bermuda' tomatoes after vacuum infiltration with ethanol vapor from $10 \mathrm{~mL}$ absolute ethanol placed in a 10-L vessel with a 3-h exposure period after infiltration. Values are means of two replications of three fruit each analyzed in triplicate. The overall standard error of means is shown.

perceivable increases in sugar levels by gluconeogenesis. Saltveit and Sharaf (1992) found that brief exposure to EtOH vapor in static conditions decreases the titratable acidity of tomatoes, but in this study no change in titratable acidity was found.

Morphological LOCATION. EtOH was normally present in the gel tissues but not in the pericarp and columella. AA was present in lower levels than EtOH in all parts of the fruit but more so in the gel. This points to differential metabolism in different tissues. The gel with its restricted intercellular air spaces was more prone to anaerobic metabolism, as indicated by the AA and EtOH accumulation, while the pericarp and columella mainly respired aerobically. Therefore whole fruit respiration measurements may be misleading if fruit morphology is not considered. As AA and EtOH products contribute directly and through remetabolization to aroma in fruit (Pesis and Avissar 1989; Pesis and Avissar 1990; Pesis et al. 1991; Shaw et al. 1991) it is also likely that the gel in tomatoes may be more responsible for aroma development or may produce a different aroma than the other tissues. The relative amounts of different tissues in tomatoes may therefore account for differences in flavor among different cultivars. Also altered atmospheres must be designed to accommodate the most anaerobically susceptible tissue in order to prevent disorders and offflavors.

When tomatoes were vacuum infiltrated with EtOH without an exposure time, there was only a minor increase in $\mathrm{EtOH}$ in the pericarp and gel, but a large increase in stem end columella tissue. This confirms that the main route of gas exchange in the tomato was via the stem scar. AA also increases in these tissues due to EtOH-induced alcohol dehydrogenase activity (Botondi et al., 1993; Massantini et al., 1995), but increases of AA are lower than initial increases in EtOH levels pointing to EtOH being metabolized to other compounds (Cossins, 1978) or being volatilized. $\mathrm{EtOH}$ and AA dissipated to control levels allowing fruit to ripen.

The pericarp route of EtOH diffusion became more important as fruit were held in EtOH after vacuum infiltration. Also during storage, there was a redistribution of $\mathrm{EtOH}$ and AA into the gel and equatorial and blossom end columella. Columella tissues returned to control $\mathrm{AA}$ and $\mathrm{EtOH}$ levels by the end of the experiment, but as the outer pericarp still contained high levels visual ripening did not proceed.

\section{Conclusions}

Breaker tomatoes could tolerate reduced pressure of $10 \mathrm{kPa}$ during vacuum infiltration together with an EtOH vapor generated by 1 to $20 \mathrm{~mL}$ in $10 \mathrm{~L}$ for not longer than 12 or $3 \mathrm{~h}$ after vacuum infiltration, respectively. A longer exposure or higher concentration caused skin pitting and uneven ripening in the fruit and in some cases off-flavor. Conditions that caused no visual injuries could be utilized to delay color changes by 1 to $5 \mathrm{~d}$ in addition to a normal ripening time of $4 \mathrm{~d}$ at $22^{\circ} \mathrm{C}$. With higher concentrations of $\mathrm{EtOH}$ and longer exposure the risk of offflavors increased, but otherwise flavor was not affected.

The distribution of EtOH and AA in different tissues indicated that the pattern of metabolic activity in the fruit was not uniform. The gel tissue appeared to be subject to anaerobic conditions, while the pericarp and columella are more aerobic, resulting in different flavor profiles in different tissues.

During EtOH vacuum infiltration, EtOH moved readily through the stem scar into the columella, but during subsequent exposure it also diffused to a lesser extent through the skin and into the pericarp. When high enough levels of EtOH and AA were obtained some volatiles diffused into the gel.

\section{Literature Cited}

Aharoni, Y., J.K. Stewart, D.G. Guadagni, and T.R. Mon. 1980. Thrips mortality and strawberry quality after vacuum fumigation with acetaldehyde or ethyl formate. J. Amer. Soc. Hort. Sci. 105:926-929.

Beaulieu, J.C. and M.E. Saltveit. 1997. Inhibition or promotion of tomato fruit ripening by acetaldehyde and ethanol is concentration dependent and varies with initial fruit maturity. J. Amer. Soc. Hort. Sci. 122:392-398.

Beaulieu, J.C., G. Peiser, and M.E. Saltveit. 1997. Acetaldehyde is a causal agent responsible for ethanol-induced ripening inhibition in tomato fruit. Plant Physiol. 113:431-439.

Berger, R.G., G.R. Dettweiler, G.M.R. Krempler, and F. Drawert. 1992. Precursor atmosphere technology: Efficient aroma enrichment in fruit cells, p. 59-71. In: R. Teranishi, G.R. Takeoka, and M. Güntert (eds.). Flavor precursors: Thermal and enzymatic conversions. Amer. Chem. Soc., Washington, DC.

Botondi, R., E. Gobattoni, R. Massantini, and F. Mencarelli. 1993. ADH activity, via ethanol, affects ethylene production in tomato pericarp discs, p. 154-155. In: J.C. Pech, A. Latché, and C. Balagué (eds.). Cellular and molecular aspects of the plant hormone ethylene. Kluwer Academic Publishers, Dordrecht.

Burdon, J., S. Dori, R. Marinansky, and E. Pesis. 1996. Acetaldehyde inhibition of ethylene biosynthesis in mango fruit. Postharvest Biol. Technol. 8:153-161.

Buttery, R.G., G.R. Takeoka, and L.C. Ling. 1995. Furaneol: Odor 
threshold and importance to tomato aroma. J. Agr. Food Chem. 43:1638-1640.

Corcuff, R., J. Arul, F. Hamza, F. Castaigne, and J. Makhlouf. 1996. Storage of broccoli florets in ethanol vapor enriched atmospheres. Postharvest Biol. Technol. 7:219-229.

Cossins, E.A. 1978. Ethanol metabolism in plants, p. 169-268. In: D.D. Hook and R.M.M. Crawford (eds.). Plant life in anaerobic environments. Ann Arbor Science Publ. Inc., Ann Arbor, Michigan.

Grierson, D. and A.A. Kader. 1986. Fruit ripening and quality, p. 241280. In: J.G. Atherton and J. Rudich (eds.). The tomato crop: A scientific basis for improvement. Chapman \& Hall, London (reprinted 1994).

Halinska, A. and C. Frenkel. 1991. Acetaldehyde stimulation of net gluconeogenic carbon movement from applied malic acid in tomato fruit pericarp tissue. Plant Physiol. 95:954-960.

Hong, J.H., S.K. Lee, and J.K. Kim. 1995. Ethanol inhibits ripening of tomato fruit. Acta Hort. 398:147-157.

Jones, R.A. and S.J. Scott. 1984. Genetic potential to improve tomato flavor in commercial $F_{1}$ hybrids. J. Amer. Soc. Hort. Sci. 109:318-321.

Kader, A.A., M.A. Stevens, M. Albright-Holton, L.L. Morris, and M. Algazi. 1977. Effect of fruit ripeness when picked on flavor and composition in fresh market tomatoes. J. Amer. Soc. Hort. Sci. 102:724-731.

Kelly, M.O. and M.E. Saltveit, Jr. 1988. Effect of endogenously synthesized and exogenously applied ethanol on tomato fruit ripening. Plant Physiol. 88:143-147.

Klieber, A., B. Ratanachinakorn, and D.H. Simons. 1996. Effects of low oxygen and high carbon dioxide on tomato cv. Bermuda fruit physiology and composition. Scientia Hort. 65:251-261.

Lizotte, P.A. and P.E. Shaw. 1992. Flavor volatiles in Valencia orange and their quantitative changes caused by vacuum infiltration of butanal. Lebensm. Wiss. Technol. 25:80-82.

Massantini, R., E. Gobattoni, R. Botondi, and F. Mencarelli. 1995. Role of alcohol dehydrogenase on ripening of ethanol treated tomato and kiwifruit. Acta Hort. 379:297-304.

McGlasson, W.B., R.L. McBride, D.J. McGrath, E.E. Smith, and D.J. Best. 1982. Influence of harvest maturity and ripening temperature on acceptability of North Queensland fresh market tomatoes. Food Technol. Austral. 34:291-293.

Paz, O., H.W. Janes, B.A. Prevost, and C. Frenkel. 1981. Enhancement of fruit sensory quality by post-harvest applications of acetaldehyde and ethanol. J. Food Sci. 47:270-273, 276.

Perata, P. and A. Alpi. 1991. Ethanol-induced injuries to carrot cells:
The role of acetaldehyde. Plant Physiol. 95:748-752.

Pesis, E. and I. Avissar. 1989. The post-harvest quality of orange fruits as affected by pre-storage treatments with acetaldehyde vapour or anaerobic conditions. J. Hort. Sci. 64:107-113.

Pesis, E. and I. Avissar. 1990. Effect of postharvest application of acetaldehyde vapour on strawberry decay, taste and certain volatiles. J. Sci. Food Agr. 52:377-385.

Pesis, E. and R. Marinansky. 1993. Inhibition of tomato ripening by acetaldehyde vapour or anaerobic conditions prior to storage. J. Plant Physiol. 142:717-721.

Pesis, E., G. Zauberman, and I. Avissar. 1991. Induction of certain aroma volatiles in feijoa fruit by postharvest application of acetaldehyde or anaerobic conditions. J. Sci. Food Agr. 54:329-337.

Pesis, E., R. Marinansky, I. Rot, and A. Weksler. 1994. Effect of postharvest application of acetaldehyde or a short period of anaerobiosis on fruit senescence. Proc. R. Soc. Edinb. 102B:473-478.

Ratanachinakorn, B., A. Klieber, and D.H. Simons. 1997. Effect of shortterm controlled atmospheres and maturity on ripening and eating quality of tomatoes. Postharvest Biol. Technol. 11:149-154.

Saltveit, Jr., M.E. 1989. Effect of alcohols and their interaction with ethylene on the ripening of epidermal pericarp discs of tomato fruit. Plant Physiol. 90:167-174.

Saltveit, Jr., M.E. and F. Mencarelli. 1988. Inhibition of ethylene synthesis and action in ripening tomato fruit by ethanol vapors. J. Amer. Soc. Hort. Sci. 113:572-576.

Saltveit, Jr., M.E. and A.R. Sharaf. 1992. Ethanol inhibits ripening of tomato fruit harvested at various degrees of ripeness without affecting subsequent quality. J. Amer. Soc. Hort. Sci. 117:793-798.

Salunkhe, D.K. and J.Y. Do. 1977. Biogenesis of aroma constituents of fruits and vegetables. CRC Crit. Rev. Food Sci. Nutr. 8:161-190.

Savarese, P. and F. Mencarelli. 1989. The use of ethanol vapours for controlling postharvest maturation in tomato. Informatore Agrario 46:46, 51-53.

Shaw, P.E., M.G. Moshonas, and E. Pesis. 1991. Changes during storage of oranges pretreated with nitrogen, carbon dioxide and acetaldehyde in air. J. Food Sci. 56:469-474.

Watada, A.E. and B.B. Aulenbach. 1979. Chemical and sensory qualities of fresh market tomatoes. J. Food Sci. 44:1013-1016.

Yamashita, I., Y. Nemoto, and S. Yoshikawa. 1975. Formation of volatile esters in strawberries. Agr. Biol. Chem. 39:2303-2307.

Yamashita, I., Y. Nemoto, and S. Yoshikawa. 1976. Formation of volatile alcohols and esters from aldehydes in strawberries. Phytochemistry 15:1633-1637. 